\title{
The Impact of Capital Structure on the Profitability of Publicly Traded Manufacturing Firms in Bangladesh
}

\author{
Md. Ataur Rahman ${ }^{1}$, Md. Sadrul Islam Sarker $^{2} \&$ Md. Joyen Uddin ${ }^{3}$ \\ ${ }^{1}$ Assistant Professor, Department of Finance and Banking, Begum Rokeya University, Rangpur, Bangladesh \\ ${ }^{2}$ Assistant Professor, Department of Management Studies, Begum Rokeya University, Rangpur, Bangladesh \\ ${ }^{3}$ MBA Student, Department of Finance and Banking, Begum Rokeya University, Rangpur, Bangladesh \\ Correspondence: Md. Ataur Rahman, Assistant Professor, Department of Finance and Banking, Begum Rokeya \\ University, Rangpur-5400, Bangladesh.
}

Received: December 12, 2018

Accepted: January 7, 2019

Available online: January 10, 2019

doi:10.11114/aef.v6i2.3867

URL: https://doi.org/10.11114/aef.v6i2.3867

\begin{abstract}
This research explores the impact of capital structure on the profitability of publicly traded manufacturing firms in Bangladesh. In this paper, we applied the fixed effect regression to find out the correlation among independent variables (debt ratio, equity ratio and debt to equity ratio) and dependent variables (return on asset, return on equity and earnings per share). A sample of 50 observations of selected 10 manufacturing companies listed in Dhaka Stock Exchange has been analyzed over the period of 2013 to 2017. This research reveals that the debt ratio and equity ratio have a significant positive impact but debt to equity ratio has a significant negative impact on ROA. This paper also exposes that, equity ratio has a significant positive impact but debt to equity ratio has a significant negative impact on ROE. Finally, debt and equity ratio has a significant negative impact on EPS. Findings of this research will help the listed manufacturing companies to maintain an optimum capital structure which will lead to the maximization of stockholders wealth.
\end{abstract}

Keywords: optimum capital structure, ROA, ROE, EPS, Bangladesh

JEL Classification: G32

\section{Introduction}

The capital structure choice of a manufacturing firm is the most significant decision taken by the management of the firm to maximize profits and at the same time minimize costs of capital leads to the maximization of stockholders wealth. Basically, there are two main sources of finance. One is internal finance which is equity and another is external finance which is debt. Most firms use a combination between equity and debt which appearance the capital structure. Modigliani and Miller (1963) stated that capital structure as the mixture between debt and equity that the firm uses in its operation. They also showed the impact of capital structure on firm's performance. After Modigliani and Miller, Jensen and Meckling (1976) discussed the relationship between capital structure and firm performance.

Further, a significant number of researches have been done to depict the impact of capital structure on firm performance in developed and developing countries. In the developed countries aspect, Tailab (2014) did research on American energy, Tifow and Sayilir (2015) did research Turkey manufacturing firm and on United Kingdom manufacturing sector small and medium enterprise (SME). From 2013 forward, most of the research done in capital structure was carried on developing countries. Ogebe, et al. (2013) did research on Nigeria firm performance. Kajananthan and Nimalthasan (2013) did research on Sri Lankan manufacturing firm, Mwangi, et al. (2014) did research on Kenya non-financial listed companies performance, Zeitun and Tian (2014) did research on Jordanian non-financial listed companies and Akeem, et al. (2014) did research on Nigeria manufacturing companies performance. Still, many researchers are trying to find out a better relationship between capital structure and firm performance.

Therefore, this research will help all the financial specialists to realize the impact of capital formation on the firm's profitability. Moreover, this research will help the company manager and stakeholder to understand more about the influence of capital structure and the sensitivity of debt and equity in the firm's activities. It will provide a guideline to the financial manager to design a better capital structure to reduce the cost of capital, raise firm profitability and 
ultimately maximize shareholder wealth. At the same time, this study can lead the investor to know more about the effect of capital structure choice on their return and form an optimal capital structure.

\section{Objectives of the Study}

The main objective of the study is to show the impact of capital structure on profitability of publicly traded manufacturing firms in Bangladesh. To fulfill the main objective we pursue the following specific objectives:

- To identify the impact of capital structure on Return on Asset (ROA).

- To identify the impact of capital structure on Return on Equity (ROE).

- To identify the impact of capital structure on Earning per Share (EPS).

\section{Literature Review}

According to Myers (1984), capital structure is the choice of debt, equity or hybrid securities for the firm to finance their business. Roshan (2009) said that capital structure is a financial structure of an entity, is a combination of debt and equity fund maintained by a firm. Finally, Brendea (2011), stated that capital structure is the long-term financing used by an entity while Nirajini and Priya (2013) added that capital structure refers to the way which the entity financed a mixture of long-term capital and short-term liabilities. Modigliani and Millers (1963) indicated that debt finance gives a tax advantage to the firm. The capital structure is relevant to the firm's value and firms are able to maximize their value by raising debt level in their capital structure (Sabin and Miras, 2015). Nirajini and Priya (2013) found a positive relationship between debt and firm profitability. Even M\&M theorem have some weakness, but it provided a basic concept for the capital structure and a foundation of other theories (Ahmad, et al., 2012). Ahmeti and Prenaj (2015) also supported MM theory goes beyond the propositions themselves.

Debt to equity formula is total debt divided by total equity. The increasing debt will raise debt to equity. Based on the trade-off theory, debt provides a tax advantage to the company (Obim, et al., 2014). Hence, increase company debt level able to reduce tax expense and raise firm performance. Therefore, debt to equity has a significant positive impact on ROA. Goh et al. (2016); and Nirajini and Priya (2013) also supported this view. Numerous studies were found a different result and indicate a debt to equity has a significant negative impact on ROA (Mwangi, et al., 2014; Sabin \& Miras, 2015; Pratheepkanth, 2011; Akeem, et al., 2014; Muhammad, et al., 2014).

Trade-off theory indicated each financial source has own benefit and cost. The firm's optimum capital structure is identified by the trade-off of the benefit and the cost of debt finance (Myers, 1984). Trade-off theory indicated higher profitability firm will be able to gain more tax advantages by increasing borrowing without risking financial distress and apply a higher portion of debt finance in the capital structure. However, trade-off theory criticizes that it is correct under the assumption of no cost of adjustment (Myers, 1984). Besides that, trade-off theory has ignored the effect of retaining earning in the capital structure, retain earning is no cost and no risk. Majority of experimental research in the past established that capital structure has a negative impact on the profitability of the manufacturing firm. Umer et al. (2012) again exposed that there is a negative correlation between capital structure and profitability of the firm. Hadlock and James (2002) concluded that companies prefer debt financing to increase their anticipated return.

Finally, we can say that there is no universal theory of the debt-equity choice. Different views have been published regarding the financing choice. The present study will also investigate the effect of capital structure on profitability of listed firms in Dhaka Stock Exchange in Bangladesh.

\section{Data and Research Methodology}

\subsection{Data and Variables}

A sample of 50 secondary observations has been collected from audited financial statements of 10 manufacturing companies listed in Dhaka Stock Exchange (DSE) during 2013-2017. To make sure valid estimates of the measures, an observation is selected on the basis of some criteria: firms with missing data for any factor in the model during the study period are dropped and sometimes adjusted; firms having the extremist values for any of capital structure are also dropped; Firms having the extremist values for any of performance variables are also dropped. Independent variables to measure profitability and dependent variables to measure capital structure are shown in the following Table 1.

Table 1. Dependent and independent variables

\begin{tabular}{llll}
\hline Nature of variables & Symbol & Explanation & Calculation \\
\hline Independent & DR & Debt Ratio & Total Debt/Total Assets \\
Independent & ER & Equity Ratio & Total Equity/Total Assets \\
Independent & DE & Debt to Equity Ratio & Total Debt/Total Equity \\
Dependent & ROA & Return on Assets & Net Income /Total Assets \\
Dependent & ROE & Return on Equity & Net Income /Equity \\
Dependent & EPS & Earnings per Share & Net Income/No. of Shares Outstanding \\
\hline
\end{tabular}




\subsection{Econometric Model}

The multiple linear regression model used in this study is as follow:

Where,

$$
P_{i t}=\alpha+\beta_{1} D R_{i t}+\beta_{2} E R_{i t}+\beta_{3} D E_{i t}+\varepsilon_{i t}
$$

$\alpha$ is constant;

$\beta_{1}$ to $\beta_{2}=$ Coefficient of determinants of independent variables;

$i$ (numbers of manufacturing firms) $=1,2,3, \ldots . .10$;

$t($ time-interval $)=1,2, \ldots .5$;

$\varepsilon$ is error term.

\section{Findings and Analysis}

\subsection{Descriptive Statistics}

The descriptive statistics show that the mean value of ROA is $0.59642 \%$ with a standard deviation of $0.572085 \%$. In addition, the variable ROA record a rather low inconsistency as the value range from $-0.7 \%$ to $2.86 \%$. The mean value of ROE is $0.899142 \%$ with a standard deviation of $1.095714 \%$, the minimum value of ROA is $-0.25 \%$ and the maximum is $5.66 \%$. Variable EPS presents relatively high inconsistency since its minimum value stands at $-.91 \%$ and maximum at $8.66 \%$. The mean value of EPS is $3.72542 \%$ with a standard deviation of $2.641485 \%$.

Table 2. Descriptive statistics of the variables used in the regression model

\begin{tabular}{llllll}
\hline Variables & Observations & Mean & Std. Dev. & Min. & Max. \\
\hline ROA & 50 & 0.59642 & 0.572085 & -0.7 & 2.86 \\
ROE & 50 & 0.899142 & 1.095714 & -0.25 & 5.66 \\
EPS & 50 & 3.72542 & 2.641485 & -0.91 & 8.66 \\
DE & 50 & 0.834974 & 0.553487 & 0.04 & 2.81 \\
DR & 50 & 0.524006 & 0.121375 & 0.255 & 0.756 \\
ER & 50 & 0.47802 & 0.125389 & 0.244 & 0.77 \\
\hline
\end{tabular}

Source: Results obtained (STATA output) by the authors.

The mean value of debt to equity ratio (DE) is $0.834974 \%$ with a standard deviation of $0.553487 \%$. In addition, the variable debt to equity ratio (DE) records moderate variability as the value range from $0.074 \%$ to $2.81 \%$. Variable debt ratio (DR) presents a mean value $0.524006 \%$ with the standard deviation of $0.121375 \%$. Its variability ranges from $0.255 \%$ to $0.756 \%$. Finally, variable equity ratio (ER) has a mean value of $0.47802 \%$ with a standard deviation of $0.125389 \%$ and record variability ranges from $0.244 \%$ to $0.77 \%$ which is lowest among all the variables.

\subsection{Correlation Matrix}

The correlation matrix of the financial ratios used in this study is presented in table 3. Equity ratio (ER) has positive correlation with ROA $(\mathrm{r}=0.0555)$, ROE $(\mathrm{r}=0.1113)$. Where ER has negative correlation with EPS $(\mathrm{r}=-0.2898), \mathrm{DE}(\mathrm{r}=$ $-0.425)$ and $\mathrm{DR}(\mathrm{r}=-0.994)$.

Table 3. Correlation matrix among variables

\begin{tabular}{lllllll}
\hline & ROA & ROE & EPS & DE & DR & ER \\
\hline ROA & 1 & & & & & \\
ROE & 0.9094 & 1 & & & & \\
EPS & 0.1008 & -0.049 & 1 & & & \\
DE & -0.2364 & -0.0855 & -0.1332 & 1 & & \\
DR & -0.0202 & -0.0697 & 0.2796 & 0.4405 & 1 & \\
ER & 0.0555 & 0.1113 & -0.2898 & -0.425 & -0.994 & 1 \\
\hline
\end{tabular}

Source: Results obtained (STATA output) by the authors. 


\subsection{Regression Result}

Table 4. The result of fixed effect regression analysis:

\begin{tabular}{llll}
\hline & ROA & ROE & EPS \\
\hline$\alpha$ & $-14.6996^{*}$ & $-30.9367^{*}$ & 14.41907 \\
DR & $16.03141^{*}$ & 32.32012 & -5.31875 \\
ER & $15.02894^{*}$ & $31.60325^{*}$ & -13.9768 \\
DE & $-0.34572^{*}$ & $-0.24805^{*}$ & $-1.46762^{*}$ \\
$\mathrm{R}^{2}$ & 0.193 & 0.1634 & 0.1649 \\
Observations & 50 & 50 & 50 \\
\hline
\end{tabular}

* Statistically significant at 5\%.

Source: Results obtained STATA output) by the authors.

In table 4, the regression result find debt ratio (DR) and equity ratio (ER) have a significant positive impact but debt to equity ratio (DE) has a significant negative impact on ROA. Equity ratio (ER) has a significant positive impact but debt to equity ratio (DE) has a significant negative impact on ROE. Finally, the debt to equity ratio (DE) has a significant negative impact on EPS. The explanatory power of the three models, $\left(\mathrm{R}^{2}\right.$ values) are; 0.193, 0.1634 and 0.1649 respectively. These indicate that $19.3 \%, 16.34 \%$, and $16.49 \%$ of the variation in the Bangladeshi manufacturing firm's return on assets and return on equity, and earnings per share respectively can be explained by the explanatory variables in each model.

\section{Conclusion}

The impact of capital structure on the profitability of the manufacturing firm is analyzed based on descriptive statistics, correlation matrix and fixed effect regression analysis. The regression result shows the debt ratio has a significant positive impact on ROA supported by Modigliani and Miller. Equity ratio has a significant positive impact on ROA and ROE. Finally, the debt to equity ratio has a significant negative impact on ROA, ROE, and EPS. In conclusion, the firms raise debt finance to reduce the cost of capital and enjoy tax advantage but debt level over the optimum capital structure has a significant negative impact on ROA, ROE, and EPS.

\section{References}

Ahmad, Z., Abdullah, N. M. H., \& Roslan, S. (2012). Capital structure effect on firm's performance: Focusing on consumers and industrials sectors on Malaysian firms.International review of business research papers, 8(5), $137-155$.

Ahmeti, F., \& Prenaj, B. (2015). A critical review of Modigliani and Miller's theorem of capital structure.

Akeem, L. B., Terer, E. K., Kiyanjui, M. W., \& Kayode, A. M. (2014). Effects of capital structure on firm's performance: Empirical study of manufacturing companies in Nigeria. Journal of Finance and Investment Analysis, 3(4), 39-57.

Brendea, G. (2011). Capital structure theories: A critical approach.StudiaUniversitatisBabes-Bolyai, 56(2), 29.

Goh, J. X., Hall, J. A., \& Rosenthal, R. (2016). Mini meta-analysis of your own studies: Some arguments on why and a primer on how.Social and Personality Psychology Compass, 10(10), 535-549. https://doi.org/10.1111/spc3.12267

Hadlock, C. J., \& James, C. M. (2002). Do banks provide financial slack? The Journal of Finance, 57(3), 1383-1419.

Jensen, M. C., \& Meckling, W. H. (1976). Theory of the firm: Managerial behavior, agency costs and ownership structure. Journal of financial economics, 3(4), 305-360. https://doi.org/10.1016/0304-405X(76)90026-X

Kajananthan, R., \& Nimalthasan, P. (2013). Capital structure and its impact on firm performance: A study on Sri Lankan listed manufacturing companies. Merit Research Journal of Business and Management, 1(2), 37-44.

Modigliani, F., \& Miller, M. H. (1963). Corporate income taxes and the cost of capital: a correction.The American economic review, 53(3), 433-443.

Muhammad, H., Shah, B., \& Ul Islam, Z. (2014). The impact of capital structure on firm performance: Evidence from Pakistan.The Journal of Industrial Distribution \& Business, 5(2), 13-20. https://doi.org/10.13106/jidb.2014.vol5.no2.13.

Mwangi, L. W., Makau, M. S., \& Kosimbei, G. (2014). Relationship between capital structure and performance of non-financial companies listed in the Nairobi Securities Exchange, Kenya. Global Journal of Contemporary 
Research in Accounting, Auditing and Business Ethics, 1(2), 72-90.

Myers, S. C. (1984). The capital structure puzzle. The journal of finance, 39(3), 574-592. https://doi.org/10.1111/j.1540-6261.1984.tb03646.x

Nirajini, A., \& Priya, K. B. (2013). Impact of capital structure on financial performance of the listed trading companies in Sri Lanka. International Journal of Scientific and Research Publications, 3(5), 1-9.

Obim, E. N., Anake, A. F., \& Awara, E. F. (2014). Relationship between Capital Structure and Firm's Performance: Theoretical Review. Journal of Economics and Sustainable Development, 5(17),72-78.

Ogebe, P., Ogebe, J., \& Alewi, K. (2013). The Impact of Capital Structure on Firms' Performance in Nigeria.

Pratheepkanth, P. (2011). Capital structure and financial performance: evidence from selected business companies in Colombo stock exchange Sri Lanka. Researchers World, 2(2), 171.

Roshan, B. (2009). Capital Structure and Ownership Structure: A Review of Literature. The Journal of Online Education, 1-8.

Sabin, D., \& Miras, H. (2015). Debt level and firm performance: A study on low-cap firms listed on the Kuala Lumpur stock exchange. International Journal of Accounting, Business and Management, 1(1), 1-17.

Salawu, R. O. (2009). The effect of capital structure on profitability: An empirical analysis of listed firms in Nigeria. The International Journal of Business and Finance Research, 3(2), 121-129.

Tailab, M. M. K. (2014). The effect of capital structure on profitability of energy American firms. International Journal of Business and Management Invention, 3(12), 54-61.

Tifow, A. A., \& Sayilir, O. (2015). Capital Structure and Firm Performance\&58; An Analysis of Manufacturing Firms in Turkey. Eurasian Journal of Business and Management, 3(4), 13-22. https://doi.org/10.15604/ejbm.2015.03.04.002

Umar, M., Tanveer, Z., Aslam, S., \& Sajid, M. (2012). Impact of capital structure on firms' financial performance: Evidence from Pakistan.

Zeitun, R., \& Tian, G. (2014). Capital structure and corporate performance: evidence from Jordan.

\section{Copyrights}

Copyright for this article is retained by the author(s), with first publication rights granted to the journal.

This is an open-access article distributed under the terms and conditions of the Creative Commons Attribution license which permits unrestricted use, distribution, and reproduction in any medium, provided the original work is properly cited. 